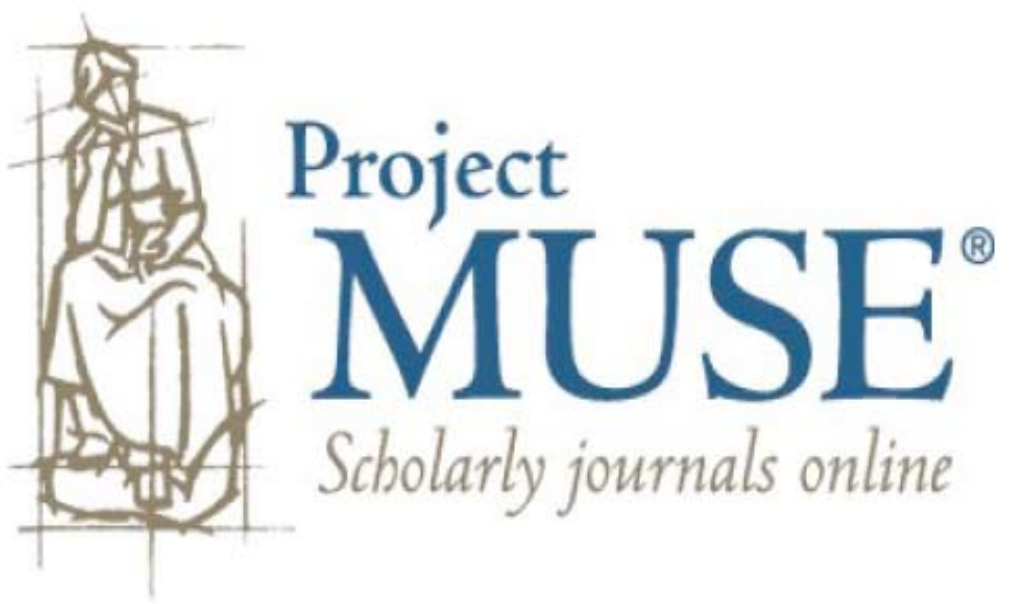




\title{
THE STATE AND \\ COORDINATED CAPITALISM \\ Contributions of the Public Sector to Social Solidarity in Postindustrial Societies
}

\author{
By CATHIE JO MARTIN and KATHLEEN THELEN*
}

\section{INTRODUCTION}

$\mathrm{D}$ OES egalitarian capitalism have a future? In the face of massive changes sparked by globalization, technological change, and the secular decline of manufacturing, students of the political economy of the advanced industrial democracies are posing this question with increased urgency. ${ }^{1}$ In the past, cooperative arrangements in many socalled coordinated market economies (CMEs) seemed well suited to reconciling high levels of economic efficiency with high levels of social solidarity. ${ }^{2}$ A large and growing literature has emerged to explain the origins and distinctive logic that separates these political economies from an alternative "liberal" model that, while equally viable in the market, is characterized by greater social and economic inequality. ${ }^{3}$

* The authors extend special thanks to Peter Hall, Torben Iversen, and John Stephens for extensive and insightful commentary on the paper. In addition, they benefited tremendously from input from Lucio Baccaro, John Campbell, Tom Cusack, Frank Dobbin, Martin Höpner, Richard Locke, Sara Jane McCaffrey, Paul Osterman, Ove Kaj Pedersen, Britta Rehder, Wolfgang Streeck, Duane Swank, Christine Trampusch, and the participants in seminars at the Copenhagen Business School, the Institute for Policy Research at Northwestern University, the Sloan School of Management at MIT, and the Center for European Studies at Harvard University. Martin thanks the Radcliffe Institute for Advanced Study (Harvard University), the German Marshall Fund, and the Danish Social Science Research Council; Thelen thanks the Institute for Policy Research (Northwestern University), the working group on "Institutional Complementarities and Institutional Change" at the Max Planck Institute for the Study of Society in Cologne, and the Max Planck Gesellschaft for support, financial and otherwise. Sebastian Karcher provided valuable research assistance.

${ }^{1}$ Jonas Pontusson, Inequality and Prosperity: Social Europe vs. Liberal America (Ithaca, N.Y.: Cornell University Press, 2005); David Rueda, "Insider-Outsider Politics in Industrialized Democracies," American Political Science Review 99 (February 2005).

${ }^{2}$ See, for example, Wolfgang Streeck, "On the Institutional Conditions of Diversified Quality Production," in Egon Matzner and Wolfgang Streeck, eds., Beyond Keynesianism (Aldershot, U.K.: Edward Elgar, 1991).

${ }^{3}$ Peter A. Hall and David Soskice, Varieties of Capitalism: The Institutional Foundations of Comparative Advantage (New York: Oxford University Press, 2001); see also Pontusson (fn. 1). For more recent extensions and elaborations of the original varieties of capitalism framework, see Torben Iversen and David Soskice, "Electoral Institutions and the Politics of Coalitions: Why Some Democracies

World Politics 60 (October 2007), 1-36 
Today, however, many of the institutional arrangements characteristic of the coordinated market economies are under intense strain, due to new market pressures and the attendant ascendance of neoliberal ideology. But if the economic and ideological challenges are clear, the politics are more contested. Some scholars fear that these experiments in cozy coordination are doomed, while others bet on continuity over change. ${ }^{4}$

The empirical record is mixed, with an impressive persistence of coordination in some countries but not in others. Although there have been significant changes in collective bargaining systems cross-nationally, some countries have sustained higher levels of coordination in policymaking channels and have managed to maintain a higher level of control in framework agreements, even while aspects of wage setting have been decentralized to lower-level units. Take Denmark and Germany-two clear, noncontroversial cases of coordinated market economies that have evolved along sharply divergent paths in the past two decades. Denmark, the new poster child of Europe, has been able to sustain rather strong institutions for coordinating politics at the national level in the face of disintegrating forces. Key reforms in the 1990s moved Denmark sharply toward "activation" policies normally associated with liberal market economies. ${ }^{5}$ Yet these initiatives emerged from consensual, tripartite bargaining, and their effects, if anything, have strengthened the organizational power of the peak associations. By contrast, Germany has drifted toward a more "disorganized" version of capitalism. ${ }^{6}$ Legislative reforms in Germany have left most of the key institutions traditionally associated with "Model Germany" formally intact; however, stability at the formal-institutional level masks a very significant erosion of coordinating capacities both within the state and on both sides of the class divide. Membership in unions and employers' associations has fallen significantly, and coverage of collective bargaining and other collective arrangements has shrunk though widespread defections. ${ }^{7}$

Redistribute More Than Others," American Political Science Review 100 (May 2006); and Thomas R. Cusack, Torben Iversen, and David Soskice, "Economic Interests and the Origins of Electoral Systems," American Political Science Review 101 (August 2007). For a recent critique, see Walter Korpi, "Power Resources and Employer-Centered Approaches in Explanations of Welfare States and Varieties of Capitalism: Protagonists, Consenters, and Antagonists," World Politics 58 (January 2006).

${ }^{4}$ See, for example, Duane Swank, Global Capital, Political Institutions, and Policy Change in Developed Welfare States (New York: Cambridge University Press, 2002).

${ }^{5}$ John Campbell, John Hall, and Ove Kaj Pedersen, eds., National Identity and a Variety of Capitalism: The Danish Case (Montreal: McGill University Press, 2006).

${ }^{6}$ Martin Höpner, "Coordination and Organization: The Two Dimensions of Nonliberal Capitalism," Discussion Paper no. 07/12 (Cologne: Max Planck Institut für Gesellschaftsforschung, December 2007).

${ }^{7}$ Anke Hassel, "The Erosion of the German System of Industrial Relations," British Journal of Industrial Relations 37 (September 1999); and Claus Schnabel, "Gewerkschaften und Arbeitgeberverbände: Organisationsgrade, Tarifbindung und Einflüsse auf Löhne und Beschäftigung," Discussion Paper no. 34 (Erlangen-Nuremberg: Friedrich-Alexander Universität, May 2005). 
This article investigates why some countries have been able to sustain national-level institutions for coordination, while others are becoming more disorganized in response to the changing economic context. The key objective is thus to explain the direction and character of institutional change as it bears on coordination. We begin by acknowledging that the broad category of coordinated market economies subsumes quite different types of cooperative engagement. Macrocorporatist forms of engagement are national-level institutions for fostering cooperation among the peak employers' associations and unions: these include both political forums for negotiating national public policy outcomes and collective bargaining channels that deliver either peak-level bargains or sectoral agreements negotiated within a national framework. Forms of coordination associated with enterprise cooperation, in comparison, occur at the level of sector or regional institutions and are often privately controlled. ${ }^{8}$

While the Scandinavian countries historically had a rather higher level of bargaining than the Christian democratic ones (at the peak rather than at the sectoral level), both groups had high levels of macrocoordination, as even the Christian democratic countries featured considerable concertation across bargaining units and high levels of cooperation in policy-making channels. In addition, to the extent that Christian democratic countries relied on enterprise cooperation, this form of engagement seemed to reinforce macrocoordination and functioned as a sort of structural equivalent, because manufacturing interests were able to play a leading role in both wage negotiations and relations with the state. ${ }^{9}$

Indeed, in the 1970s and 1980s enterprise coordination was widely viewed as superior for achieving macroeconomic performance, since countries in which the state loomed especially large (for example, Denmark and Sweden) seemed to be listing under the weight of high public consumption. ${ }^{10}$ Yet with the advent of a service sector economy, private arrangements for coordination in manufacturing can no longer substitute for public coordinating mechanisms, as exposed sectors are shrinking in employment and the needs of core industrial workers are becoming in-

\footnotetext{
${ }^{8}$ This difference corresponds roughly to the distinction drawn by Katzenstein, between social and liberal corporatism, and by Soskice, between centrally and sectorally coordinated systems. See Peter J. Katzenstein, Small States in World Markets (Ithaca, N.Y.: Cornell University Press, 1985); and David Soskice, "Wage Determination: The Changing Role of Institutions in Advanced Industrial Countries," Oxford Review of Economic Policy 6, no. 4 (1990).

${ }^{9}$ Kathleen Thelen, Union of Parts: Labor Politics in Postwar Germany (Ithaca, N.Y.: Cornell University Press, 1991).

${ }^{10}$ Torben Iversen and Jonas Pontusson, "Comparative Political Economy: A Northern European Perspective," in Torben Iversen, Jonas Pontusson, and David Soskice, eds., Unions, Employers, and Central Banks (New York: Cambridge University Press, 2000).
} 
creasingly distinct from the rest of society. As a consequence, the subcategories of coordination-macrocorporatism and enterprise cooperation - seem to be associated with different patterns of politics offering different capacities for self-adjustment. We thus wish to understand what allows some countries but not others to cope with the essential problematic of sustaining national-level coordination while adjusting for economic change.

We argue that differences in the role and the size of the state are at the heart of the divergence among European coordinated countries, because state policy is key to forging and sustaining broad national coalitions that link-rather than separate-diverse interests (such as manufacturing versus services and labor-market insiders versus outsiders). A large public sector (1) has an impact on the strategic interests of government bureaucrats, by expanding their interests in improving the skills of the long-term unemployed, (2) expands the capacities of bureaucrats to construct political coalitions of private sector groups to support state policies, and (3) alters the strategic interests of private actors. In short, we argue that the relative power and distinctive interests of the state are crucial factors in sustaining particular varieties of coordination across time within countries.

Our argument directly challenges the received wisdom in three important ways. First, we reject a central tenet of neoliberal theorizing that the state is a constraint on adjustment and suggest instead that the state is more important than ever in facilitating continued coordination. A large public sector (typically written off as an inevitable drag on the economy) can actually provide state actors with a critical political tool for shoring up coordination in a postindustrial economy.

Second, while we agree with a large varieties-of-capitalism literature that sees employer coordination as crucial for defining coordinated market economies, we question the widespread tendency in that literature to view such coordination as a self-sustaining equilibrium. Just as state policy was crucial historically in forging coordination in virtually all arenas of the political economy, ${ }^{11}$ state support is essential for maintaining coordination today in the face of new pressures. Thus, in renegotiating cooperative arrangements, countries that have traditionally relied on state policy to shore up coordination between the social partners have a distinct edge over countries that have relegated coordination to private-interest associations.

\footnotetext{
${ }^{11}$ See, for example, Kathleen Thelen, How Institutions Evolve: The Political Economy of Skills in Germany, Britain, the United States and Japan (New York: Cambridge University Press, 2004).
} 
Third, our emphasis on the critical and positive role played by the public sector calls into question a long-standing political truism in comparative political economy - that leadership by the export sector will produce the best collective outcomes. ${ }^{12}$ In a context in which employment in manufacturing is declining, a competitive export sector (even with wage restraint) is no longer even remotely sufficient to generate the jobs needed to sustain full employment. Moreover, to the extent that the interests of the (often still highly successful) exposed sectors come to diverge from those of other sectors, strong and well-organized manufacturing interests can pose a serious obstacle to reform efforts that can be overcome only through strong and proactive intervention under the auspices of the state. ${ }^{13}$

The article is organized as follows. We begin by unpacking the notion of coordination and explore the role of the state in sustaining different varieties of coordination. We use the cases of Denmark and Germany to illustrate how the state, in its capacity as provider of social and collective goods and as employer/service provider, matters to institutional outcomes. We conclude with implications for the study of institutional change in advanced political economies.

\section{InSTITUTIONAL ADAPTATION AND VARIETIES OF COORDINATION}

At the heart of the CME ideal type is the observation that employers coordinate in order to achieve mutually beneficial goals, most importantly though not exclusively to secure a highly skilled workforce. Yet coordination can be achieved in a number of distinctive ways: while these may be functionally equivalent from the perspective of individual firms, they have very different implications for macropolitical dynamics and distributional outcomes. A somewhat more differentiated framework is therefore necessary, one that retains the core distinction between liberal and coordinated market economies, while also capturing the distinctive trajectories of change within CMEs. In this mode Martin Höpner situates coordinated capitalism on a scale ranging from "organized" to "disorganized" and recognizes that coordination can transpire

${ }^{12}$ Colin Crouch, "Trade Unionism in the Exposed Sector," in Renato Brunetta and Carlo Dell'Aringa, eds., Labor Relations and Economic Performance (New York: New York University Press, 1990); and Geoffrey Garrett and Christopher Way, "Public Sector Unions, Corporatism, and Wage Determination," in Iversen, Pontusson, and Soskice (fn. 10).

${ }^{13}$ Wolfgang Streeck, "Industrial Relations: From State Weakness as Strength to State Weakness as Weakness: Welfare Corporatism and the Private Use of the Public Interest," in Simon Green and William E. Paterson, eds., Semi-sovereignty Revisited: Governance, Institutions, and Policies in United Germany (Cambridge: Cambridge University Press, 2005). 
at various levels. ${ }^{14}$ In a similar vein Hicks and Kenworthy distinguish between state-led macrocorporatist processes and what they call enterprise cooperation, or microcorporatism..$^{15}$ Recognition of these multiple avenues of coordination allows us both to assess the real impact of putatively liberal policy reforms within coordinated market economies and to discern more subtle changes in the scope and character of coordination that would otherwise not register in the classic varieties-ofcapitalism framework.

Following these analyses, we distinguish two varieties of coordination: macrocorporatism and enterprise coordination. Macrocorporatism utilizes national associational forms of institutional cooperation that imply high levels of coordination in the representation of the interests of labormarket actors, in collective bargaining processes, and in employers' and unions' participation in national tripartite policy-making forums. In keeping with other analyses, our components of macrocorporatism conceptually include three types of national coordinating measures. First, measures of centralization and density capture the degree to which the national associations representing employers and labor are centralized and the scope of their coverage; thus, these measures constitute an evaluation of peak federation power over members. The proportion of the potential membership that actually belongs to the association is indicative of the association's capacity to make credible claims to speak for the entire social group it purports to represent. The centralization and the density of the peak associations are important both to the negotiation of collective bargains and to the political representation of interests.

Second, a measure of sectoral coordination captures the integration of industry-level collective bargaining agreements across the economy. Collective bargains are clearly highly coordinated when negotiated by a single peak association representing each of the social partners; but in addition, national coordination occurs when industry-level settlements are linked across sectors either through strong pattern bargaining or through framework agreements. Denmark and Sweden, for example, have recently decentralized bargaining down to the industrial level but

\footnotetext{
${ }^{14}$ Höpner (fn. 6). For Höpner, disorganized capitalism is characterized by cooperative relations organized according to a relatively narrow microeconomic logic (for example, cooperative relations between firms and their local labor representatives and with suppliers), whereas organized capitalism is characterized by the "embedding" of such microeconomic rationality in the service of broader collective interests.

${ }^{15}$ Alexander Hicks and Lane Kenworthy, "Cooperation and Political Economic Performance in Affluent Democratic Capitalism," American Journal of Sociology 103 (May 1998); see also Cathie Jo Martin and Duane Swank, "Does the Organization of Capital Matter?" American Political Science Review 98 (November 2004), 599.
} 
have preserved national coordination through framework agreements. Thus our second measure of macrocorporatism examines coordination in wage bargaining across the economy, either at the peak association level or at the industry level in which sectoral bargains are coordinated with each other through a broad framework agreement.

Third, policy process integration represents the integration of employers and unions in national policy-making processes. ${ }^{16}$ Here the emphasis is on the political representation of the labor-market partners and their capacity to make highly organized, collective demands for public policy and, in turn, to help with the implementation of policy outcomes.

Ideally, we would like to gather data for both employers and unions in each of these measures of macrocorporatism; yet good cross-national data on membership in employer associations are notoriously difficult to obtain. We therefore use Hicks and Kenworthy's empirical measures of these three aspects of macrocorporatist organization among employers (centralization, sectoral coordination, and policy process integration). These measures were developed into an index by Martin and Swank, and we have added to this index a measure of the density of labor unions to augment our measure of the persistence of nationallevel coordinating institutions. ${ }^{17}$ We note that the limited extant data on membership in employers' associations are consistent with the broad movements in union density; for example, Danish employers' association membership has increased slightly since 1990, whereas comparable German membership has been declining. ${ }^{18}$

Our other type of coordination, referred to by Martin and Swank as "enterprise cooperation," ${ }^{19}$ entails coordination among firms or between firms and workers at a more intermediate level; this cooperation is less national in focus and may evolve without direct ongoing state participation. The forms of coordination that are captured in the concept of enterprise cooperation are varied. They include, for example, tightly coordinated connections among purchasers and suppliers, often involving joint or shared efforts in areas like research and development and training. Another facet of enterprise cooperation would be coordination

\footnotetext{
${ }^{16}$ Colin Crouch, Industrial Relations and European State Traditions (New York: Oxford University Press, 1993); Franz Traxler, Sabine Blaschke, and Bernhard Kittel, National Labour Relations in Internationalized Markets (New York: Walter de Gruyter, 2001); Hicks and Kenworthy (fn. 15); Martin and Swank (fn. 15).

${ }^{17}$ Martin and Swank (fn. 15).

${ }^{18}$ Martin Behrens and Franz Traxler, "Employers' Organisations in Europe," EIROnline (April 2004).

${ }^{19}$ Martin and Swank (fn. 15).
} 
among competing firms within the same industrial sector, in technology development or skills, or in some cases in marketing; often such forms of coordination are organized in the context of trade associations or chambers of commerce. Long-term relations between firms and investors - for example, between companies and their "house banks" (associated in the literature with "patient capital")—would also belong in this category. And finally, the kind of cooperation that such relations engender often provides the underpinnings for other dimensions of enterprise cooperation, including teamwork-based production at the firm level or intrafirm departments working in multidivisional project teams. Hicks and Kenworthy ${ }^{20}$ provide empirical measures of this form of coordination.

These divergent types of coordination entail fundamentally different roles for state intervention to facilitate societal cooperation. Enterprise cooperation may require virtually no state intervention, while macrocorporatism needs governments to organize tripartite forums and national collective bargaining processes. Thus while enterprise cooperation often occurs far from the center of national government, macrocorporatism is very much a political artifact. These categories are by no means logically inconsistent alternatives to one another, as countries may score high on both dimensions. Nevertheless, in the past some nations have featured high levels of coordination based on private enterprise cooperation to achieve collective goals.

Figure 1 demonstrates that countries form clusters determined by their modes of coordination. The $\mathrm{y}$-axis records an assessment of the strength of national coordinating associations: the measure evaluates union density and corporatist organization in employer associations. The $\mathrm{x}$-axis reports the level of enterprise cooperation. As is readily apparent in the figure, advanced industrialized countries fall into three clusters. Scandinavian countries demonstrate high levels of both national-level coordination (or macrocorporatism) and enterprise cooperation, while some Christian Democratic countries have slightly higher levels of enterprise cooperation but medium to low levels of macrocorporatism. Liberal countries have low scores for both types of cooperation.

With the decline of industrial capitalism and the shift to service sector capitalism, the coordinating institutions developed in the industrial golden age may be under siege, and many scholars have pointed to the problems of sustaining the institutions of macrocorporatism in particular. The core industrial sector is shrinking as a proportion of the entire

${ }^{20}$ Hicks and Kenworthy (fn. 15). 


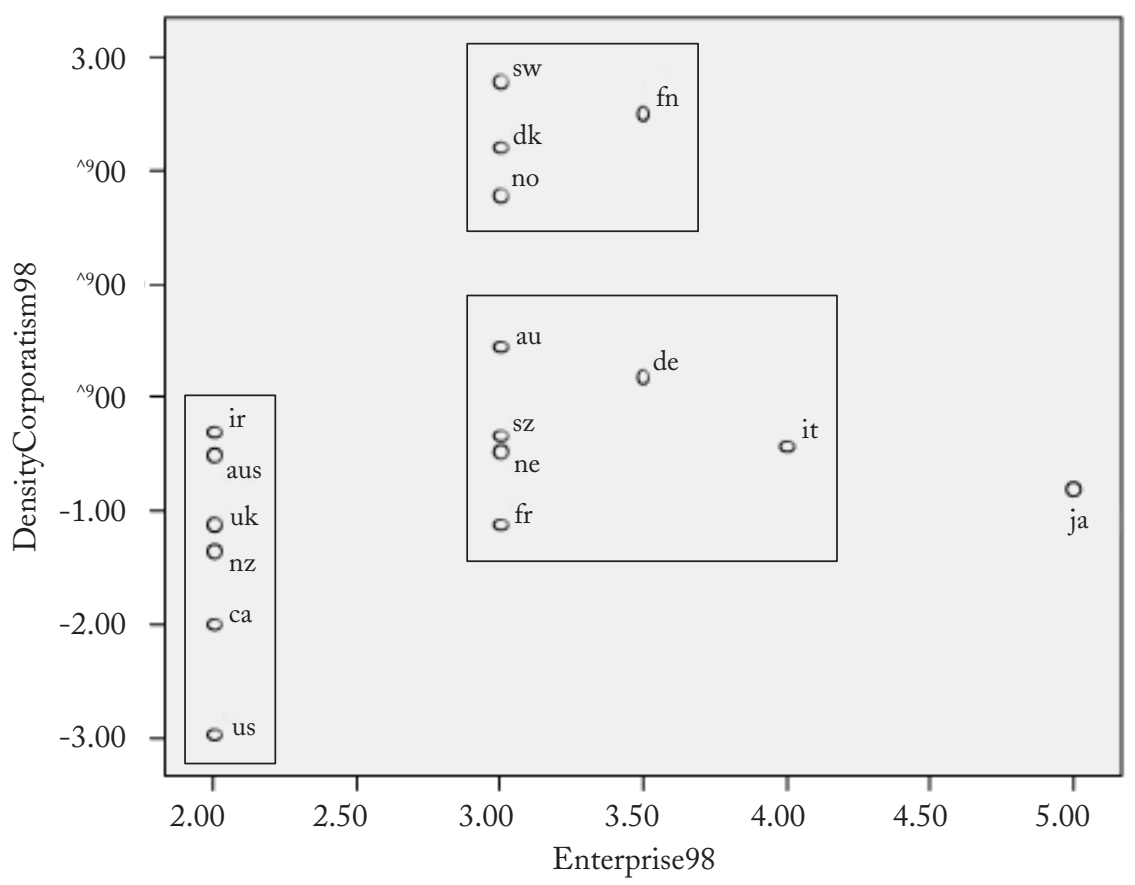

FiguRe 1

National Associational Coordination by Enterprise Cooperation ${ }^{a}$

SouRces: The data on union density are taken from Martin and Swank and are derived from Jelle Visser, "Trade Union Membership Database" (Manuscript, Sociology of Organizations Research Unit, Department of Sociology, University of Amsterdam, March 1992); idem, "Unionization Trends Revisited," Research Paper 1996/2 (Centre for Research of European Societies and Industrial Relations [CESAR], February 1996), with updates provided to Duane Swank by Bernhard Kittel. The corporatism index constitutes three measures of corporatism: employer centralization, coordination among employers, and incorporation of employers into corporatist policy-making forums. The employercentralization data are taken from Miriam Golden, Michael Wallerstein, and Peter Lange, "Union Centralization among Advanced Industrial Societies," electronic database at www.shelly.polisci.ucla .edu/data. The employer-coordination data are taken from Layard, Nickell, and Jackman 1991 and updated by Duane Swank. See Richard Layard, Stephen Nickell, and Richard Jackman, Unemployment: Macroeconomic Performance and the Labor Market (New York: Oxford University Press, 1991). The data on incorporation of employers into corporatist policy-making forums are derived from Traxler, Blaschke, and Kittel (fn. 16). The Enterprise98 variable is a measure of economic coordination among enterprises, including the extent of long-term purchaser-supplier alliances, alliances among competing firms for R\&D, training and standard setting, work teams, project teams linking departments and functional divisions within firms, and linkages between finance and industry. Data are taken from Hicks and Kenworthy (fn. 15) and were updated by Duane Swank.

We have excluded Belgium for purposes of displaying the clusters more sharply.

${ }^{a} y$-axis $=$ National associational coordination, a measure of union density combined with a measure of corporatist organization in employers' associations for 1998; $\mathrm{x}$-axis $=$ Enterprise Cooperation for 1998. 
economy, industrial production has moved to developing countries with globalization, and behemoth manufacturing firms are breaking down into component parts. ${ }^{21}$ Service sector workers and firms are notoriously poorly organized. Thus, the institutions for collective action constructed in a previous era for manufacturing interests may not fit the needs of the emerging service economy. As an example, Germany's acclaimed national system of apprenticeship training continues to perform vital functions for manufacturing companies but has yet to take off in the service sector. ${ }^{22}$

Moreover, the rise of nonaccommodating monetary policy has made it difficult to sustain institutions for macrolevel coordination. As Iversen has argued, advanced industrial countries can secure noninflationary economic growth either through centralized collective bargaining combined with expansionary fiscal and monetary policies or through industry-level or even firm-level wage bargaining combined with a nonaccommodating monetary policy. ${ }^{23}$ When leftist governments pursued Keynesian accommodationist strategies during the industrial golden age, export sectors were persuaded to ally themselves with low-wage workers to maintain centralized bargaining (and to hold in check the inflationary demands of militant sheltered sector workers). But with the development of a nonaccommodating monetary regime, rightist governments and producers in exposed, high-skill sectors were at liberty to support a shift to industry-level bargaining. The choice of equilibrium positions in this argument is very much a matter of politics, and as countries came to favor a nonaccommodating monetary regime over Keynesian strategies, macrocorporatism and social solidarity were also threatened. ${ }^{24}$

In fact, in evaluating the relative resilience of different modes of coordination, a large literature in the 1990s saw the more centralized cases of macrocorporatism as more fragile than enterprise-based coordination and anticipated a convergence of the institutional arrangements in the Nordic countries on the more decentralized German model. The prediction was that with the adoption of nonaccommodationist monetary policies, governments would increasingly move away from macrocorporatist institutions for coordination. Trends in Scandinavia-including the decentralization of wage bargaining and the embrace of nonaccommodating monetary policies - seemed to point to a shift toward the al-

${ }^{21}$ OECD observer, 2005.

${ }^{22}$ Pepper Culpepper and Kathleen Thelen, "Institutions and Collective Actors in the Provision of Training: Historical and Cross-National Comparisons," in Karl Ulrich Mayer and Heike Solga, eds., Skill Formation: Interdisciplinary and Cross-National Perspectives (New York: Cambridge University Press, 2007).

${ }^{23}$ Torben Iversen, Contested Economic Institutions (New York: Cambridge University Press, 1999).

${ }^{24}$ Ibid., chap. 4. 
ternative equilibrium and a convergence on the Germanmodel. ${ }^{25}$ Denmark seemed to be a clear case of change, whereas Germany seemed to demonstrate institutional stability.

Yet recent structural changes in the economy, in particular, the decline of industrialism, have also posed problems for countries that have relied more extensively on enterprise cooperation. Under industrial capitalism, the private cooperative arrangements between business and labor in manufacturing functioned as a structural equivalent of stateled corporatism, by setting labor-management conditions for the entire economy despite the more limited role for government. ${ }^{26}$ Under service sector capitalism, however, mechanisms for translating enterprise cooperation into overarching solidarity are receding. In countries such as Germany that rely heavily on enterprise cooperation, large companies and workers in the industrial core who used to act on behalf of the entire economy now have greater difficulty meeting this task and compensating for the limited (and declining) membership in unions and employers' associations. The concerns and interests of the ever-shrinking core workforce are increasingly divergent from those of other workers, especially workers outside manufacturing, and the state has limited capacity to overcome the interests of monopoly capital in order to represent the 75 percent of the total workforce found in other sectors. ${ }^{27}$

Thus, although distinct varieties of coordinated capitalism have always existed, the differences have become more pronounced with the decline of manufacturing, and the clusters of CMEs have become more separate over time. Contrary to expectations in the 1990s, the Scandinavian cluster has proved more successful in sustaining institutions for macrocoordination. In Denmark and Sweden, for example, while bargaining has been decentralized to the industrial sector level as predicted by Pontusson and Iversen, a system of negotiating broad climate agreements has reinforced coordination among sectors. Perhaps even more significantly, however, the state has helped the peak associations to continue to play a role in organizing the political representation of the social partners, and this has helped the associations to stay vibrant in the face of fragmenting change. The temporal divergence within subgroups of coordinated market economies is apparent in measures of union density, an indicator for which excellent cross-national data are available. To this end, Figures 2 and 3 chart countries' union density

\footnotetext{
${ }^{25}$ Iversen (fn. 23), 199; Iversen and Pontusson (fn. 10); Jonas Pontusson, "Between Neo-Liberalism and the German Model: Swedish Capitalism in Transition," in Colin Crouch and Wolfgang Streeck, eds., Political Economy of Modern Capitalism (London: Sage, 1997).

${ }^{26}$ Katzenstein (fn. 8); Thelen (fn. 9).

${ }^{27}$ See also Streeck (fn. 13).
} 


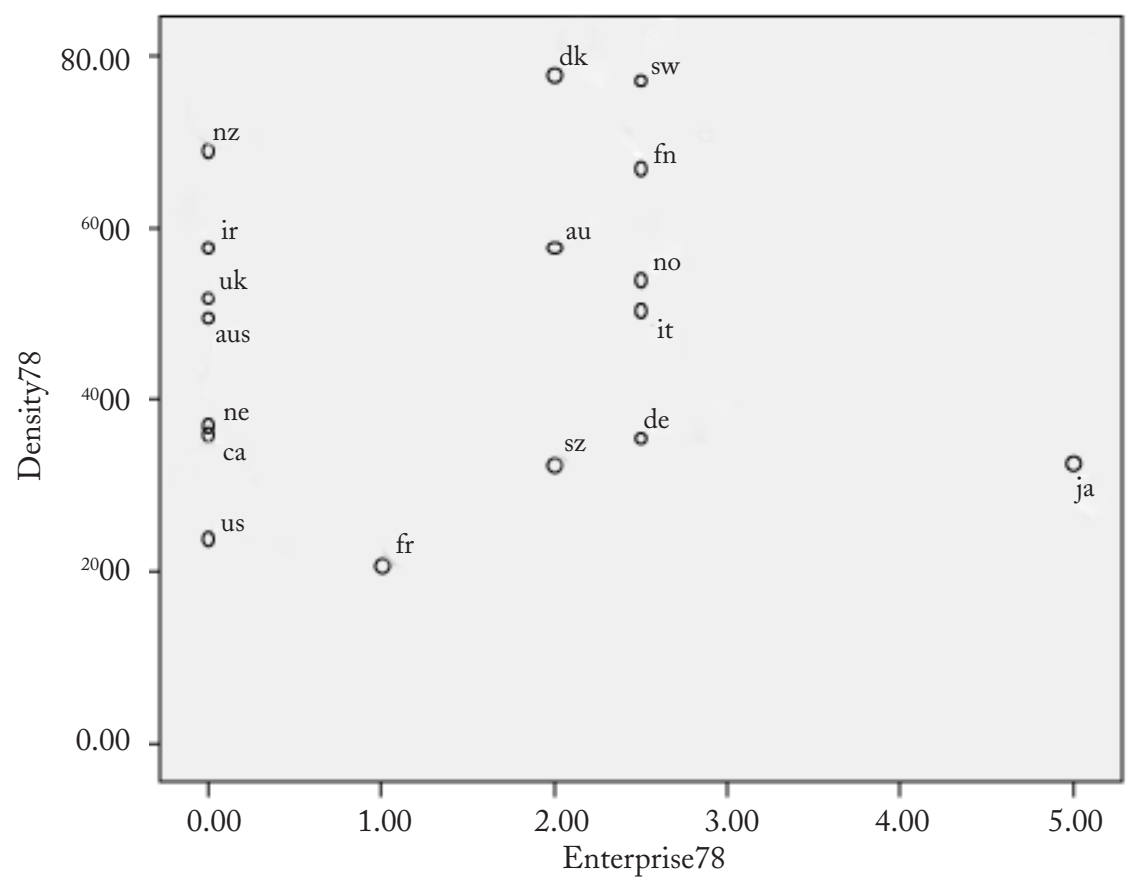

Figure 2

Union Density For 1978 by ENTERPRISE COOPERATION FOR 1978a

Sources: Density78 is a measure of union density taken from the oECD, "Labour Market Statistics," published online as www1.oecd.org/scripts/cde/members/lfsindicatorsauthenticate.asp. The data were adjusted for nonactive and self-employed members by Jelle Visser in accordance with the model used by Ebbinghaus and Visser. See Bernhard Ebbinghaus and Jelle Visser, Trade Unions in Western Europe since 1945, ed. P. Flora, F. Kraus, and F. Rothenbacher (New York: Palgrave, 2000).

The Enterprise78 variable measures the same features of Enterprise 98 described above and the data are also taken from Hicks and Kenworthy (fn. 15).

${ }^{\mathrm{a}} \mathrm{y}$ axis $=$ Union Density for 1978; $\mathrm{x}$ axis $=$ Enterprise Cooperation for 1978.

by level of enterprise cooperation for 1978 and 2001 and demonstrate significant movement for the period. The clusters that clearly congeal by 2001 were overall much less recognizable in 1978.

As Table 1 demonstrates, union density fell for all but the social democratic countries (where density rates actually increased on average). This decline made the greatest contribution to the emergence of clearly recognizable clusters among the coordinated market economies; further, the spatial distribution of countries would be even more pronounced were the data to extend to 2006. Germany, for example, retains high levels of enterprise cooperation (on issues like research and development, purchaser-supplier relations, and especially plant-based 


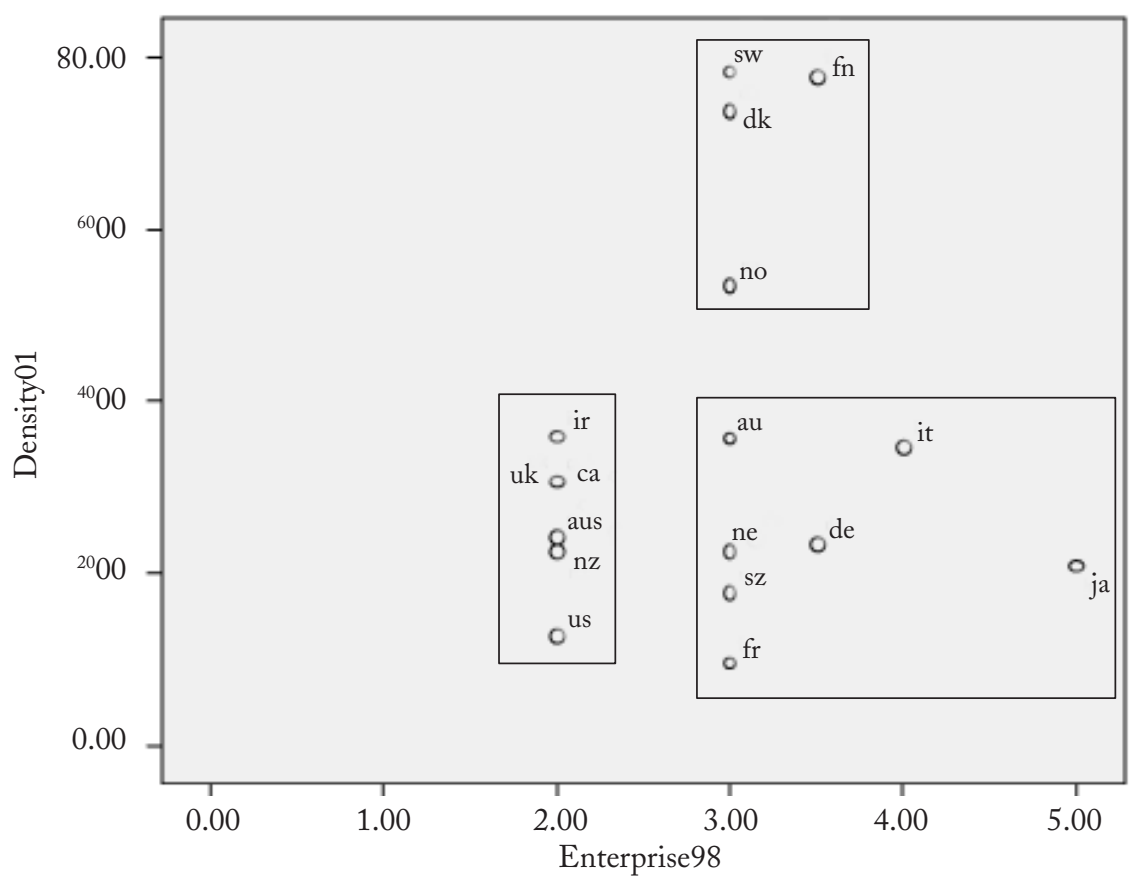

FiguRE 3

Union Density for 2001 by ENTERPRise CoOperation For 1998a

SOURCES: Density01 is a measure of union density taken from the OECD, "Labour Market Statistics," published online at www1.oecd.org/scripts/cde/members/lfsindicatorsauthenticate.asp. The data were adjusted for nonactive and self-employed members by Jelle Visser in accordance with the model used by Ebbinghaus and Visser; Bernhard Ebbinghaus and Jelle Visser, Trade Unions in Western Europe since 1945, ed. P. Flora, F. Kraus, and F. Rothenbacher (New York: Palgrave, 2000).

The Enterprise 98 variable is estimated like the Enterprise 78 variable described in the sources for Figure 1 but is for 1998 data.

${ }^{a} \mathrm{y}$-axis $=$ Union Density for 2001; $\mathrm{x}$-axis $=$ Enterprise Cooperation for 1998.

cooperation between local labor representatives and employers); yet its drop in union density is noteworthy. ${ }^{28}$

Also striking is the movement in enterprise cooperation (presented in Table 2); yet rather than becoming more liberal, all countries are becoming more coordinated. Japan (of course), Italy, Germany, and Finland lead in enterprise cooperation, although most countries gained in this measure

${ }^{28}$ Reliable data on firm membership in employers associations is notoriously difficult to obtain, but what evidence does exist suggests a greater drop-off in Germany than in Denmark. This includes significant declines even in manufacturing since the 1980s; see Martin Behrens, "New Study Analyses Development of Employers' Associations," EIROnline (December 2002). We acknowledge that the Ghent system also sustains union density but emphasize here an additional factor that has an independent impact on increasing unionization rates: the growth of the public sector. The growth of the public 
TABLE 1

Changes in Union Density

(1978-2001)

\begin{tabular}{lllll}
\hline \hline & 1978 & 2001 & \multicolumn{2}{c}{ Change, $1978-2001$} \\
\hline Australia & 49.5 & 24.3 & -25.2 & $(-50.9 \%)$ \\
Austria & 57.6 & 35.7 & $-21.9(-38.0 \%)$ \\
Canada & 36 & 30.7 & $-5.3(-14.7 \%)$ \\
Denmark & 77.8 & 73.8 & -4.0 & $(-5.1 \%)$ \\
Finland & 66.9 & 77.8 & $+10.9(+16.3 \%)$ \\
France & 20.7 & 9.6 & -11.1 & $(-53.6 \%)$ \\
Germany & 35.5 & 23.5 & $-12.0(-33.8 \%)$ \\
Ireland & 57.6 & 35.9 & -21.7 & $(-37.7 \%)$ \\
Italy & 50.4 & 34.8 & -15.6 & $(-31.0 \%)$ \\
Japan & 32.6 & 20.9 & -11.7 & $(-35.9 \%)$ \\
Netherlands & 37 & 22.6 & -14.4 & $(-38.9 \%)$ \\
New Zealand & $69(1979)$ & 22.6 & -46.4 & $(-67.2 \%)$ \\
Norway & 54 & 53.6 & -0.4 & $(-0.7 \%)$ \\
Sweden & 77 & 78.3 & +1.3 & $(+1.7 \%)$ \\
Switzerland & 32.5 & 17.8 & -14.7 & $(-45.2 \%)$ \\
United Kingdom & 51.8 & 30.7 & -21.1 & $(-40.7 \%)$ \\
United States & 23.9 & 12.8 & -11.1 & $(-46.4 \%)$ \\
\hline
\end{tabular}

SouRCES: These data on union density are taken from the OECD, "Labour Market Statistics," published online at www1.oecd.org/scripts/cde/members/lfsindicatorsauthenticate.asp. The data were adjusted for nonactive and self-employed members by Jelle Visser in accordance with the model used by Ebbinghaus and Visser 20; Bernhard Ebbinghaus and Jelle Visser, Trade Unions in Western Europe since 1945, ed. P. Flora, F. Kraus, and F. Rothenbacher (New York: Palgrave, 2000)

between 1978 and 1998. Contrary to the varieties-of-capitalism predictions, liberal countries expanded their rates of cooperation the most, although their absolute levels remained lower than those of the coordinated market economies. We view this phenomenon as entirely consistent with the enthusiasm for Japanese-style innovations - such as quality circles and closer relations between purchasers and suppliers- that transformed shop floors across the Western world in the 1980s.

It appears, therefore, that different countries have very different capacities for sustaining macrocoordination and social solidarity. Well into the first decade of the twenty-first century, the convergence of these coordinated market economies on the German model has failed to materialize and, despite changes in the economic context and massive policy shifts,

sector has been important in sustaining union density because public sector workers have been an important proportional source of recent union growth in many countries, whether or not they are on the Ghent system. Thus with the decline of unionization among manufacturing workers (and the decline of the manufacturing workforce), the expansion of the public sector also props up unionization. 
TABLE 2

Changes in Enterprise CoOperation ${ }^{a}$

(1978-98)

\begin{tabular}{|c|c|c|c|c|c|c|c|c|c|c|}
\hline & $\begin{array}{c}\text { purchas } \\
\text { supplier } \\
1978\end{array}$ & 1998 & $\begin{array}{l}\text { compet } \\
\text { firms } \\
1978\end{array}$ & 1998 & $\begin{array}{c}\text { work } \\
\text { teams } \\
1978\end{array}$ & 1998 & $\begin{array}{c}\text { project } \\
\text { teams } \\
1978\end{array}$ & 1998 & $\begin{array}{c}\text { finance } \\
\text { indust } \\
1978\end{array}$ & 1998 \\
\hline AUS & .00 & .50 & .00 & .50 & .00 & .50 & .00 & .50 & .00 & .00 \\
\hline $\mathrm{AU}$ & .50 & .50 & .50 & .50 & .00 & .50 & .00 & .50 & 1.00 & 1.00 \\
\hline $\mathrm{CA}$ & .00 & .50 & .00 & .50 & .00 & .50 & .00 & .50 & .00 & .00 \\
\hline DK & .50 & .50 & .50 & .50 & .00 & .50 & .00 & .50 & 1.00 & 1.00 \\
\hline $\mathrm{FN}$ & .50 & .50 & 1.00 & 1.00 & .00 & .50 & .00 & .50 & 1.00 & 1.00 \\
\hline FR & .00 & .50 & .00 & .50 & .00 & .50 & .00 & .50 & 1.00 & 1.00 \\
\hline GE & .50 & .50 & 1.00 & .50 & .00 & 1.00 & .00 & .50 & 1.00 & 1.00 \\
\hline IR & .00 & .50 & .00 & .50 & .00 & .50 & .00 & .50 & .00 & .00 \\
\hline IT & .50 & 1.00 & 1.00 & 1.00 & .00 & .50 & .00 & .50 & 1.00 & 1.00 \\
\hline JA & 1.00 & 1.00 & 1.00 & 1.00 & 1.00 & 1.00 & 1.00 & 1.00 & 1.00 & 1.00 \\
\hline $\mathrm{NE}$ & .00 & .50 & .00 & .50 & .00 & .50 & .00 & .50 & .00 & 1.00 \\
\hline $\mathrm{NZ}$ & .00 & .50 & .00 & .50 & .00 & .50 & .00 & .50 & .00 & .00 \\
\hline $\mathrm{NO}$ & .50 & .50 & .50 & .50 & .50 & .50 & .00 & .50 & 1.00 & 1.00 \\
\hline SW & .50 & .50 & .50 & .50 & .50 & .50 & .00 & .50 & 1.00 & 1.00 \\
\hline $\mathrm{SZ}$ & .50 & .50 & .50 & .50 & .00 & .50 & .00 & .50 & 1.00 & 1.00 \\
\hline UK & .00 & .50 & .00 & .50 & .00 & .50 & .00 & .50 & .00 & .00 \\
\hline US & .00 & .50 & .00 & .50 & .00 & .50 & .00 & .50 & .00 & .00 \\
\hline
\end{tabular}

Source: These data on enterprise cooperation are taken from Hicks and Kenworthy (fn. 15) and were updated by Duane Swank.

${ }^{a}$ purchas supplier $=$ extent of long-term purchaser-supplier alliances; compet firms = extent of alliances among competing firms for R\&D, training, standard setting etc.; work teams = extent of work teams; project teams $=$ extent of project teams linking departments and functional divisions within firms; finance indust = extent of linkages between finance and industry.

Denmark still features high levels of macrolevel coordination that coexist even with the development of a nonaccommodating monetary regime and some decentralization in collective bargaining. Moreover, the apparent stability of many of the formal institutional arrangements of the German system is misleading to the extent that it masks significant erosion of coordinating capacities among both employers and unions and the accompanying hollowing out these institutions. Liberalization can affect political economies along either the dimension of coordination or the dimension of organization, to use Höpner's terms. In fact, much of the movement we observe in some CMEs today consists less in a wholesale dismantling of coordinating capacities than in a reconfiguration of coordination along more flexible-less broadly solidaristic-lines. ${ }^{29}$

\footnotetext{
${ }^{29}$ Kathleen Thelen and Ikuo Kume, "Coordination as a Political Problem in Coordinated Market Economies," Governance 19 (January 2006).
} 
Our puzzle, then, is to explain why the different types of coordination demonstrate varied levels of resiliency in the face of the new disorganizing tendencies associated with contemporary political and economic trends. In other words, beyond demonstrating that different approaches to coordination exist, we must explain why some countries are better able than others to preserve high levels of macrocoordination. The next section presents our argument that a strong state and, indeed, a large public sector are the keys to understanding these outcomes.

\section{The State and Coordinated Capitalism}

It is a commonplace in the political economy literature to be skeptical of the notion that a large public sector is a good thing; in fact, the word "bloated" comes to mind as perhaps the most frequently invoked modifier. We argue, however, that a large and well-organized public sector has a political impact on the interests and strategic options of both state and private sector actors in the political economy. Partisan leadership is clearly an important part of the politics of social solidarity, ${ }^{30}$ and the size of the state (and public sector) are certainly products of past partisan-political choices. What we are emphasizing here, however, is that states with large public sectors now (regardless of current partisan composition) have both stronger interests and greater capacity to shore up macrocorporatist institutions. Specifically, we argue that a large public sector has an impact (1) on the strategic interests of government bureaucrats, (2) on the capacities of bureaucrats to build political coalitions of private sector groups to support their policies (and, thus, on the balance of power between the public and private sectors), and, consequently, (3) on the strategic interests of private actors.

First, a large public sector gives state bureaucrats greater incentives to create policies for labor-market outsiders. Government bureaucrats everywhere are motivated to do something about the long-term unemployed, in order to control the rising costs of passive social assistance and unemployment insurance benefits. But the interests of states with a large public sector are different from those of states with smaller governments. Where job expansion has been pursued by expanding public sector employment, there is a greater potential for low-skilled workers to be hired by the state. ${ }^{31}$

\footnotetext{
${ }^{30}$ On this, see especially Torben Iversen and John D. Stephens, "Partisan Politics, the Welfare State and Three Worlds of Human Capital Formation," Comparative Political Studies (forthcoming).

${ }^{31}$ Our argument here resonates with an older literature on the role and interests of state bureaucrats as an autonomous influence on public policy and on state capacities vis-à-vis private sector interests. See especially Theda Skocpol, "Bringing the State Back In," in Peter Evans, Dietrich Rueschemeyer, and Theda Skocpol, eds., Bringing the State Back In (New York: Cambridge University Press, 1985).
} 
In such cases, state actors have a keen interest in expanding the skills and productivity of low-wage workers. They need to justify public expenditures, ${ }^{32}$ but they also need to augment the human capital of their own labor force. This motivation has increased with the shrinking of the welfare state and the tightening fiscal climate. By contrast, in countries where the public sector is smaller (and has not been the site of employment expansion as a response to unemployment) state bureaucrats are more likely to respond to a state fiscal crisis by streamlining their operations and shedding labor. In the former, but not in the latter, state bureaucrats will be forced to look beyond passive employment schemes. Instead, they will need to press for skill development among low-skilled workers and to support measures that impose collective constraints on wage growth.

Second, a large public sector influences mightily the dynamics of coalition building and enhances the government's political capacity to sustain macrocorporatist institutions and to bring employers' associations and unions into political coalitions in support of social solidarity. A large public sector expands the capacity of government bureaucrats and party leaders to wield power over private sector interests, because the public sector is a more powerful constituency by virtue of its sheer size. Private business and labor groups should be more willing to cooperate with one another (and with state actors) to preserve their jurisdiction against the intrusion of a large state. Thus, the strong economic dualism that is associated with a large public sector can also be important in inspiring greater cooperation between the social partners in the private sector, encouraging them to organize not only against an external enemy (foreign competitors) but also against an internal competitor (the public sector). ${ }^{33}$

Third, a large public sector has a direct impact on private actors' strategic calculations of their own interests. ${ }^{34} \mathrm{~A}$ large public sector alters the background employment context in ways that make it easier for government bureaucrats to sustain institutions for coordination that include both labor-market insiders and labor-market outsiders. At a very fundamental level, a large public sector elevates both employment and unionization rates. This, in turn, directly expands job opportunities,

\footnotetext{
${ }^{32}$ Paul Spiker, "The Welfare State and Social Protection in the United Kingdom," in Maurice Mullard and Simon Lee, eds., The Politics of Social Policy in Europe (Lyme, N.H.: Edward Elgar, 1997).

${ }^{33}$ Partisan leadership is again obviously important to the construction of new political coalitions around policy initiatives, such as those to expand employment for the long-term unemployed. See Iversen and Stephens (fn. 30); and Martin and Swank (fn. 15). What we are emphasizing here, however, is that a large public sector has an impact on the capacities of these party leaders to construct such coalitions.

${ }^{34}$ And here we are inspired by Iversen's insightful work on the impact of state policies on private actors' strategic interests (fn. 23).
} 
eases the incorporation of marginal workers into the economy, and ameliorates the divide between high-skilled and low-skilled workers. Thus, lower rates of unemployment reduce the zero-sum conflicts between employed labor-market insiders (who pay for the welfare state) and labor-market outsiders (who are supported by it). ${ }^{35} \mathrm{~A}$ high level of state spending also has multiplier effects that sustain employment and consumption in the face of external shocks and serve as counterweight to the loss of manufacturing jobs. ${ }^{36}$ Scandinavian states today certainly recognize the limits of the strategy of locating employment growth in the public sector; indeed, the thrust of active labor-market policy has been to target the private sector as the engine of job creation. Yet the public sector in these countries is likely to stay large, in part because it employs large numbers of women who value the financial independence their jobs afford them and need the services that are provided by the state to sustain their dual-career families. ${ }^{37}$

In addition, the strategic calculations of public sector employers can have an impact on the expression of interests by the export sector, a key veto player in virtually all coordinated market economies. ${ }^{38}$ In countries with a large and well-organized public sector, government employers have become a viable ally for low-wage, low-skill service sector workers in support of macrocorporatism that can stand up to a shrinking (but still politically potent) exposed high-skill sector. Where the export sector faces no such alliance-where the public sector is small and disorganized and therefore not an effective ally-the export sector is likely to be free to go its own way and unlikely to be amenable to mobilization on behalf of low-wage workers and labor-market outsiders.

Thus, a strong state and a large public sector shore up national coordinating capacities in their impact on government strategies and capacities and in their impact on alliances and strategic options of other actors (especially but not exclusively the export sectors). The former inspires greater attention to social solidarity, while the latter supports a political climate favorable to its realization.

Admittedly, this is a rather iconoclastic argument. Esping-Andersen believes, for example, that social democratic welfare regimes, with their

\footnotetext{
${ }^{35}$ Isabela Mares, Taxation, Wage Bargaining and Unemployment (New York: Cambridge University Press, 2006).

${ }^{36}$ Wendy Carlin and David Soskice, "European Unemployment: The Role of Aggregate Demand and Institutions" (Manuscript, 2006).

${ }^{37}$ Evelyne Huber and John Stephens, "Welfare State and Production Regimes in the Era of Retrenchment," in Paul Pierson, ed., The New Politics of the Welfare State (Oxford: Oxford University Press, 2001).

${ }^{38}$ Iversen (fn. 23).
} 
expansive numbers of public sector employees, experience conflict between public and private sector workers, because protected sector workers have fewer concerns about restraining wages than employees in the exposed sectors. ${ }^{39}$ Crouch and Garrett and Way also view the growing power of public sector workers as threatening the ability of private sector workers to negotiate responsible policies that sustain global competitiveness. ${ }^{40}$ In our model, however, a large public sector actually inspires higher levels of cooperation both within the private sector and between the private and public sectors.

Here the gentle reader might protest that we are ignoring the economic impact of a large public sector, such as the potential drain on public coffers and the drag on private sector growth. It is beyond the scope of this article to parse the economic ramifications and comparative advantages of a strategy of high employment, yet scholars have recently offered tantalizing evidence about the economic benefits of macrocorporatist interventions. Large public sectors support full employment that, in turn, provides incentives for employers to maintain high levels of wage coordination and narrows the distance between labor-market insiders and outsiders. ${ }^{41}$ High levels of service sector employment, associated with a large public sector, may provide a counterweight to the loss of manufacturing jobs in mature industrial democracies. In addition, state spending has multiplier effects that sustain employment and consumption in the face of external shocks. ${ }^{42}$ Moreover, countries with large public sectors are more likely to have institutions for encouraging skill development and other social spending on growth-enhancing collective goods that may be particularly important in the transition to a postindustrial economy. ${ }^{43}$ At a minimum, we can certainly note that a large public sector and high levels of social solidarity do not seem to have harmed the Danish economy in recent years. In fact, Denmark is outperforming Germany on most of the relevant economic indicators. ${ }^{44}$

\footnotetext{
${ }^{39}$ Gosta Esping-Anderson, Welfare States in Transition (Thousand Oaks, Calif.: Sage Publications, 1996).

${ }^{40}$ Crouch (fn. 12); Garrett and Way (fn. 12).

${ }^{41}$ Lane Kenworthy, Egalitarian Capitalism (New York: Russell Sage Foundation, 2004); Mares (fn. 35); Rueda (fn. 1). Scholars differ, however, on whether high levels of public sector employment lead to low unemployment or just produce higher levels of labor-force participation.

${ }^{42}$ David Soskice, "Macroeconomics and Varieties of Capitalism," in Martin Rhodes, Bob Hancke, and Mark Thatcher, eds., Beyond Varieties of Capitalism (Oxford: Oxford University Press, 2006); Huber and Stephens (fn. 37).

${ }^{43}$ Geoffrey Garrett, Partisan Politics in the Global Economy (New York: Cambridge University Press, 1998); Torben Iversen, Capitalism, Democracy, and Welfare (New York: Cambridge University Press, 2005).

${ }^{44}$ For example, real GDP grew at an average annual rate of about 2.5 percent between 1993 and 2005 in Denmark, but at an average rate of below 2 percent in Germany (Paris: OECD, 2006).
} 
Returning to political outcomes, our core concern, the logic of our argument should lead us to find an empirical relationship between a country's having a large public sector and its ability to sustain high levels of national cooperative activity. Figure 4 demonstrates that countries with large public sectors do indeed tend to maintain high levels of national associational coordination. Thus the measure of national associational coordination (a variable estimating union density and an index of coordination among employers' associations) and the variable estimating the size of the public sector are correlated at .64 and are significant at the .01 level.

Denmark and Germany illustrate this close relationship between the size of the public sector and national mechanisms for coordination. Both countries exhibited high levels of coordination in the early postwar decades, yet pursued different cooperative tracks in later years. In the 1960s the two countries' public sectors were similar in size yet by the mid-1990s were wildly divergent. In 1960 general government employment as a percentage of the working-age population was 7.5 percent in Denmark, compared with Germany's 5.6 percent. Yet while Danish public employment increased almost threefold to 22 percent of the working-age population by 1995, German public employment increased only to 9.8 percent. Similarly, in 1960 government consumption expenditures as a percentage of gross domestic product was just over 13 percent in both countries; however, by 1994 Denmark spent 26 percent compared with Germany's 18 percent. ${ }^{45}$

To further probe the effects of the state and public sector on processes of coordination, we examine the politics of adjustment in Denmark and Germany. Both countries have struggled to preserve the spirit of cooperation that has been their hallmark throughout the postwar era and to sustain their rich welfare states in the face of globalization, technological restructuring, and demographic change. Yet we find important distinctions in the roles of the Danish and German states in facilitating adjustment to the new economic climate and in bringing employers and labor organizations to take responsibility for marginal workers. These distinctions support our primary theoretical assertion about the state's role in the politics of institutional maintenance and change. The following discussion presents mirror-image stories of struggle in the two countries over social reform and reveals the limits of associational action in the absence of state support and direction.

\footnotetext{
${ }^{45}$ Thomas Cusack, Ton Notermans, and Martain Rein, "Political-Economic Aspects of Public Employment," European Journal of Political Research 17 (July 1989). Data to 1995 from Thomas Cusack database.
} 


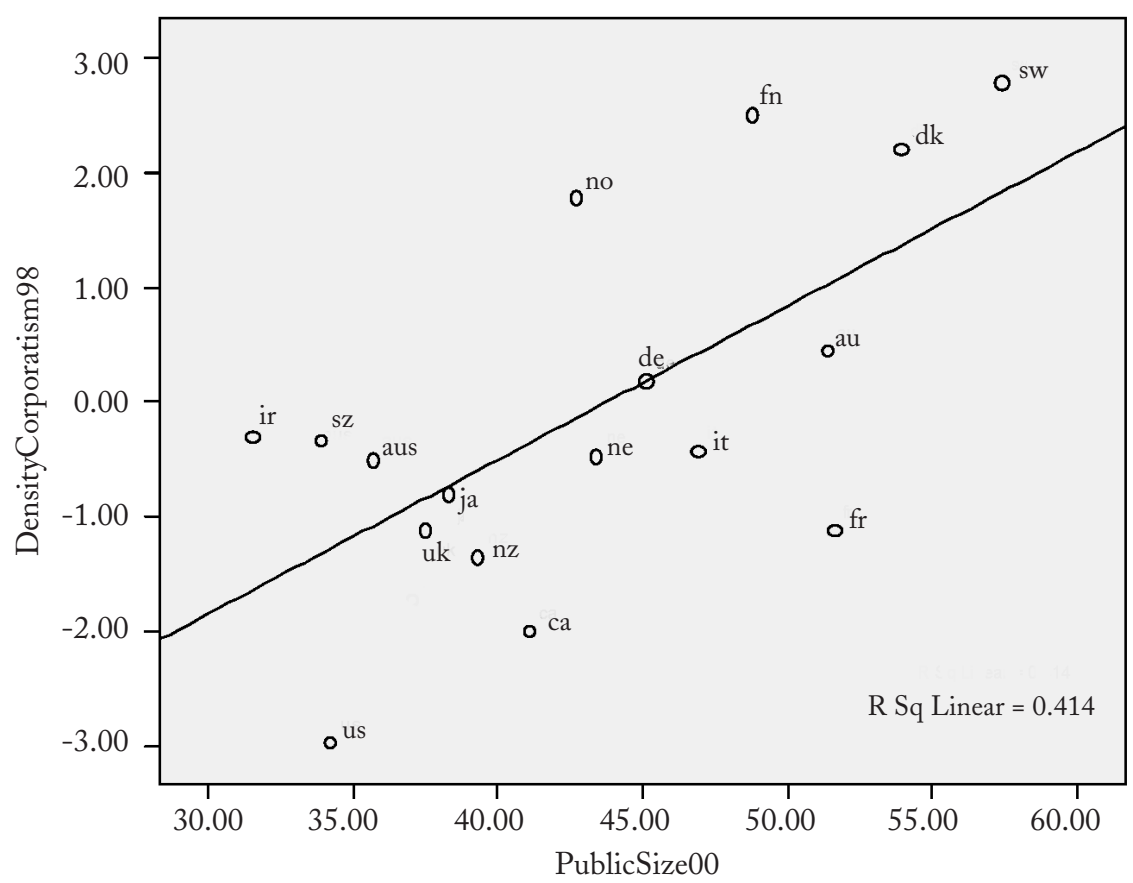

FIGURE 4

National Associational Coordination 1998 by Public Sector Size 2000a

SouRCES: PublicSize00 is a measure of general government total outlays as a percent of nominal GDP for 2000. The data are taken from OECD, "General Government Total Outlays," Economic Outlook, no. 78 (December 2005), table 25, available at http://www.oecd.org/document/61/0,2340,en_2649_201 185_2483901_1_1_1_1,00.html. The DensityCorporatism98 variable is a measure of union density and the corporatism index for the year 1998 and is described in the sources for Figure 1.

${ }^{a} y$-axis = National associational coordination, a measure of union density combined with a measure of corporatist organization in employers' associations for 1998; $\mathrm{x}$-axis = Public Sector Size as measured by general government total outlays as a percentage of nominal GDP for 2000 .

\section{The Large Public Sector and Macrocorporatism in Denmark}

From the vantage point of a few decades ago, it might be surprising that Denmark has been able to sustain high levels of macrocorporatist coordination, given the intense pressures on the Danish industrial relations system and welfare state such as structural unemployment, social exclusion, and demographic predictions of future labor shortages. Confronted with unemployment problems before many other CMEs, Denmark had rates of 8.3 percent by $1978 .{ }^{46}$ In a context in which gen-

${ }^{46}$ Fritz Scharpf, "Economic Changes, Vulnerabilities and Institutional Capabilities," in Fritz Scharpf and Vivien Schmidt, eds., Welfare and Work in the Open Economy (Oxford: Oxford University Press, 2000), 46-47. 
erous unemployment benefits came "close to full income replacement for the large majority of the wage earners" on a rather long-term (fouryear) basis, the state found itself supporting a growing population of welfare recipients. ${ }^{47}$ These pressures on the Danish economy and society led to the election of a neoliberal regime in the early 1980s, and for some time it was believed that Denmark (as well as Sweden), in decentralizing collective bargaining processes and rolling back welfare state benefits, was either moving toward neoliberalism or converging on the German model. ${ }^{48}$

Yet the Danish state seems to have avoided both an endorsement of rampant neoliberalism and a turn to the German model and, instead, has managed to strengthen its institutions for macrocorporatism in order to make them more suitable for the changing economic circumstances. The essential question, then, is how was macrocorporatism preserved? We point to the role of the Danish state, with its large public sector, in fending off the disintegrating challenges and in preserving macrocorporatist institutions. We explore the processes by which the large and powerful public sector sustained macrocorporatism in two policy areas: in maintaining macrocoordination in collective bargaining (despite the decentralization of wage negotiations to the industry level) and in constructing political coalitions in support of active labormarket programs to integrate the long-term unemployed.

\section{Maintaining High Levels of Coordination in the Collective BARGAINING REALM}

The role of the Danish state is readily apparent in the preservation of macrocorporatist institutional arrangements in the area of collective bargaining. Denmark historically had a system of highly centralized collective bargains covering a broad cross-section of the Danish economy. Basic agreements were negotiated by the very highly organized Danish Employers' Confederation (DA) and the Danish Confederation of Trade Unions (LO) and laid the groundwork for industry-level negotiations about wages and related issues. ${ }^{49}$ Yet strains on the Danish model of collective bargaining began to appear in the 1980s, and by the early 1990s wage negotiations were decentralized to the industry level. DA laid off a large portion of its staff, the DA and LO had much greater

\footnotetext{
${ }^{47}$ Kåre Hagen, “The Interaction of Welfare States and Labor Markets," in Jon Eivind Kolberg ed., The Study of Welfare State Regimes (Armonk, N.Y.: M. E. Sharpe, 1992), 153-63; Steen Scheuer, "Denmark: Return to Decentralization," in Anthony Ferner and Richard Hyman, eds., Industrial Relations in the New Europe (Oxford: Blackwell, 1992), 180.

${ }^{48}$ Campbell, Hall, and Pedersen (fn. 5); Iversen and Pontusson (fn. 10).

${ }^{49}$ Scheuer (fn. 47); Jesper Due, Joergen Steen Madsen, Carsten Stroeby Jensen, and Lars Kjerulf Petersen, The Survival of the Danish Model (Copenhagen: DJoEF Publishing, 1994).
} 
difficulty developing national agreements, and national multi-industry agreements gave way to single-industry bargaining. ${ }^{50}$

This period saw much less stability in the Danish system of collective bargaining, and in those years in which the social partners could not arrive at consensus, the government had to intervene in collective bargaining rounds. One pronounced intervention followed an intensely destabilizing period of industrial conflict in April and May 1998, when the social partners were unable to produce a deal in the 1998 bargaining round. After ten days of industrial strife, costing employers about 600 million kroner a day, the Folketing passed a bill ending the conflict and imposing a settlement on the social partners. ${ }^{51}$

The social partners bitterly resented the state's interference, which they considered an infringement of their jurisdictional rights over collective bargaining, but the experience led to the development of a new type of "climate agreement" in September 1999. The climate agreement format set certain fundamental rules for sectoral bargains in preparation for the 2000 collective bargaining rounds, in effect, creating a framework for coordinating sectoral collective bargaining. Thus the threat of state intervention prompted the social partners to organize to preserve their autonomy in collective bargaining. ${ }^{52} \mathrm{~A}$ representative of one employers' association explained that business and labor worked together like "Siamese twins" in the struggle to protect their autonomy in labor-market policy. ${ }^{53}$

The size of the Danish public sector provided some of the motivation to shore up collective bargaining institutions. Public sector bureaucrats were called upon to fulfill a dual role of worrying about the overall financing of the state and of setting the wages of the many state and municipal workers in the large public sector. Consequently, municipal employers were motivated to exercise wage restraint in wage bargaining with their workers and have struggled to ensure that wages do not hurt the budgets of municipal governments. ${ }^{54}$ Both public sector employers and workers have signed on to an "incentive model" for wages, in an

\footnotetext{
${ }^{50}$ Due et al. (fn. 49); Scheuer (fn. 47); Carsten Strøby Jensen, Jørgen Steen Madsen, and Jesper Due, "Arbejdsgiverorganisering I Danmark-et institutionssociologisk perspektiv på arbejdsgiverorganiseringens betydning for den danske arbejdsmarkedsmodel," provided by Carsten Strøby Jensen; Colin Gill, Herman Knudsen, and Jens Lind, "Are There Cracks in the Danish Model of Industrial Relations?" Industrial Relations Journal 29 (March 1998).

${ }^{51}$ F. Kåre and V. Petersen, "Parliament Intervenes to End Major Conflict," EIROnline (May 1998); Jensen, Madsen, and Due (fn. 50); Ugebrevet Mandag Morgen, "Arbejdsmarked: Markant aftale bringer LO or DA tilbage paa scenen" 32, no. 20 (September 9, 1999).

${ }_{52}$ Strøby Jensen, Madsen, and Due (fn. 50); Ugebrevet Mandag Morgen, September 1999.

${ }^{53}$ Author interview with industry respondent, Copenhagen, February 2001.

${ }^{54}$ Carsten Jørgensen, "Complicated Negotiations Start in Public Sector," EIROnline (December 2004).
} 
effort to sustain solidarity while accepting the need for wages linked to productivity. The interests of public sector employers are revealed in recent wage negotiations. For example, while public sector workers have pushed for the linkage of wages in the public sector to trends in the private sector (the "regulation mechanism"), municipal employers have struggled to ensure that these wages do not hurt municipal budgets. ${ }^{55}$ Public sector employers have also pushed for greater wage flexibility at the local level (the New Wage system), while workers want to maintain solidaristic wages. Yet public sector employees are also cognizant of the potential conflict of interest between wage increases and the overall fiscal integrity of the state. Thus labor leaders have accepted the need for some constraint in wage developments, for example, accepting the compromise incentive model proposed by the employers, in which some percentage of general increases can be used for incentives. ${ }^{56} \mathrm{In}-$ deed, while wage constraint has more frequently come from public sector employers, public sector workers also seem willing to tolerate wage settlements that ensure the fiscal solvency of the state.

\section{Constructing Coalitions to Support Active Labor-Market Programs For Labor-Market Outsiders}

The importance of a large and powerful public sector is even more evident in Denmark's ability to sustain institutions of macrocoordination in the creation of social and labor-market policies for the long-term unemployed. The Danish government, with participation from all of the parties, passed important labor-market and social reforms in the 1990s that expanded the rights of long-term unemployed people to receive individually tailored skills training and that set time limits on their receipt of passive benefits. ${ }^{57}$ The plans sought to involve private employers to the fullest extent possible, by encouraging firm-based training (as most training had previously been provided by the state), offering subsidies of about 50 percent of wages for hiring the unemployed for time-limited periods and creating new permanent wagesubsidized protected jobs for the disabled unemployed. ${ }^{58}$

While the full range of causal determinants of these policies is beyond the scope of this article, we argue that the large public sector had

\footnotetext{
${ }^{55}$ Carsten Jørgensen, “New Agreement Concluded in Local Public Sector," EIROnline (February 2005).

${ }^{56}$ Jørgensen (fn. 54).

57 "Danmarks Nationale Handlingsplan for Beskaeftigelse 1999" (Copenhagen: Arbejdesministeriet, May 1999).

${ }_{58}$ Teknologisk Institut, Fleksjob på fremtidens arbejdsmarked (Aarhus, Denmark: Teknologisk Institut, May 2000), 11
} 
an important impact on both the articulation of the interests of state actors and the government's ability to construct political coalitions in support of these active programs. First, the size of the public sector (and especially of the local governments) was important to the articulation of the interests of public sector actors. The climate of enhanced fiscal restraint, combined with the Danish practice of expanding employment through public sector work, made government managers (especially at the municipal level) increasingly concerned about productivity and cost-effective strategies for meeting their social obligations. These managers sought to develop flexibility in both the skills of the workforce and the operation of the unemployment offices; thus, the social and labor-market reforms reflected productivity and administrative concerns. ${ }^{59}$ Productivity needs also motivated bureaucrats to shift some of the burden of the long-term unemployed to private firms: state actors feared being forced to create jobs for the unemployed within government (especially at the local level) at precisely the point at which there was greater pressure to deliver services more efficiently. The municipal employers' association (Kommunernes Landsforeningen, KL) was especially vocal in raising concerns about who would offer all of the protected jobs and pressed for a "proper ratio" between the public and private sectors. ${ }^{60}$ Thus, the active labor-market reforms were first put on the public agenda by municipal bureaucrats struggling to resist challenges to the large welfare state. Denmark's neoliberal government under Poul Schluter in the 1980s set out to roll back the welfare state, in large part by devolving responsibility for social provision to the municipalities in a sort of block grant approach. (Schluter got some support from the left for this project, because decentralization would give municipalities more discretion and control.) The large municipalities resisted devolution as a form of fiscal cutback and managed to limit the neoliberal overtones of the experiment. ${ }^{61}$ At the same time local governments seeking to enhance the productivity of both marginal workers and the welfare state began experimenting with active social policies long before these ideas bubbled up to the level of national debate.

Second, the large and powerful Danish state was key to building coalitions in support of the new labor-market programs. While the large and strong municipalities were key actors in the country's move to endorse active labor-market and social policies, they did not want

${ }_{59}$ Mikkel Mailand. Den danske model lokalt og regionalt (Copenhagen: Copenhagen University FAOS, 2000), 127-29.

${ }^{60}$ Author interview with KL, Copenhagen, March 2001.

${ }^{61}$ Bent Schou, "Udgiftsstyring eller fornyelse?" in Karl Henrik Bentsen, ed., Fra Vakst til Omstilling (Copenhagen: Frederiksberg Bogtrykkeri, 1998). 
to assume all responsibility for the long-term unemployed and worked hard to incorporate other labor-market actors into this project. ${ }^{62}$ Thus, it was not enough that special programs were created for the labormarket outsiders; the municipalities wanted private sector employers to participate in these jobs and training programs and sought a concrete commitment from the private sector to do its share. ${ }^{63}$

Getting the social partners involved in the creation of policies for labor-market outsiders was a profound break from the past (since social assistance, unlike unemployment insurance, was left to the state) and was accomplished through careful framing, institution building, and implicit threats to circumvent the authority of the business and labor organizations. Following the Ghent system, unemployment benefits for workers and social assistance for groups outside of the core economy have been administered through separate channels in Denmark. While municipalities administer social assistance to the uninsured unemployed in Denmark, benefits for insured workers are controlled by special labor funds, and rules about these benefits are devised through collective bargaining and tripartite committees. Thus asking employers to take responsibility for unemployed persons not eligible for social insurance was a huge shift in social policy.

The government put active labor-market and social reforms on the political agenda with the creation of two blue-ribbon committees launched in 1991: the Labor Market Commission (also commonly referred to as the Zeuthen Commission) and the Social Commission (Sociale Udvalg). These committees included representatives from both employers' associations and unions; thus the social partners were brought into the process of constructing the new policies from the beginning. Danish government policy entrepreneurs framed the issues in a way that made it difficult for the social partners not to endorse new state programs, urging them to satisfy their own long-term selfinterests by working to advance collective economic and social interests. Linked to the collective social goal of ending social exclusion was a new economic formula for ending unemployment called the "encompassing labor market"; the formula suggested that an economy can be expanded to bring the socially excluded into its fold. ${ }^{64}$

The Danish state also worked to build support for its programs by strengthening the employers' associations and labor unions, and it managed to link the fortunes of employers' associations to success with the

\footnotetext{
${ }^{62}$ Author interview with Jørgan Sønnergård, Copenhagen, May 2001.

${ }^{63}$ Author interview with Kommunernes Landsforeningen, KL, Copenhagen, March 2001.

${ }^{64}$ Social Ministry, “Det angaar os alle” (Copenhagen: Social Ministry, January 1999).
} 
reforms. The associations were, in a sense, trying to reinvent themselves in order to cope with the decentralization of collective bargaining and were looking for other functions. One large organization in the Danish employers' sector explained that creating networks in policy areas was a new way to attract members:

The networks provide, along with other things, a platform from which firms can figure out what they think about issues. Firms may want to develop a profile in various areas such as social or environmental issues. ... Most Danish firms are fairly small, so that they cannot develop these profiles on their own. They need an organization that does more than collective bargaining, that helps to explain to firms their position on issues. . . Today the associations have to come up with reasons for members to pay for belonging to a group, such as to develop political positions. ${ }^{65}$

Certainly governments across Europe sought to drum up support among private sector actors for labor-market and social reforms, but what gave Denmark an edge in this effort was the size of the public sector, especially at the local level. Local governments created important initiatives to enhance the involvement of corporatist organizations in social policy. For example, following the tradition of representatives from business and labor overseeing labor-market policy, similar corporatist groups were set up in the social policy area. Since 1999 public law requires each municipality to have a social coordination committee (Sociale Koordinations Udvalg) to oversee the implementation of social policy and efforts to reduce unemployment in the community. ${ }^{66}$ Municipalities created a position of company consultant, a staff person to help individual firms find jobs for the unemployed. In one cross-national study, Danish employers reported much higher rates of outreach from municipal bureaucrats than did their counterparts in Britain. ${ }^{67}$ Thus, a large and powerful public sector strengthened the state's capacity for bringing private sector social partners into the project of incorporating the long-term unemployed into the core economy.

\section{The Public Sector and the Failure of Tripartism in Germany}

Since the 1980s Germany has been beset by just the sorts of problems of unemployment and social exclusion that confronted Denmark. In 2006 German unemployment averaged 9.8 percent, significantly above

${ }^{65}$ Author interview with organizational representative, Copenhagen, November 2000.

${ }^{66}$ Ibid., 23-24.

${ }^{67}$ Cathie Jo Martin, "Reinventing Welfare Regimes: Employers and the Implementation of Active Social Policy," World Politics 57 (October 2004). 
the EU-15's average of 7.7 percent, and well over double the Danish rate of 3.9 percent. ${ }^{68}$ While unification clearly exacerbated these problems, the failure of the German political economy to generate employment is actually a long-standing problem. ${ }^{69}$ Unlike in Denmark, however, repeated attempts at tripartite negotiations failed in the 1990s and into the 2000s. Instead, the most significant reforms came when the social democrats abandoned negotiated solutions and imposed the so-called Hartz reforms. ${ }^{70}$

The core of the reform is organized, as in Denmark, around activation, although the form and the content differ in important ways. Similar to Denmark, one of the main changes was a drastic reduction of unemployment benefits, for older workers from three years of benefits pegged to previous income to one year of such support. In Germany, those who exhaust these benefits then fall back on much lower levels of (flat-rate) support on a means-tested basis, so that activation in the German case operates mostly through sheer removal of benefits. Other aspects of the reform encourage employment by exempting low-earner workers from taxation and social security contributions. The state directly created some (low-paying) public works jobs but the German reforms do not include the same levels of private-sector participation and active state support for reintegration (for example, through subsidies and support for retraining) featured in the Danish flexicurity model.

For present purposes, it is important to underscore the differences, in the process and in the politics, from the Danish outcomes. The package of reforms associated with Danish flexicurity was broad and sweeping, involving large numbers of firms in retraining initiatives, entailing new roles and responsibilities for the social partners, and mobilizing considerable state resources to soften the line between labor-market insiders and outsiders. Germany's Hartz IV reforms reflect a different process: the reforms were accomplished around and without the social partners, they reproduce rather than bridge the divide between unemployment insurance and social assistance, and they exacerbate insider/ outsider cleavages by pushing marginal workers into various irregular or atypical employment in which wages and benefits are significantly below those enjoyed by "regular" workers.

\footnotetext{
${ }^{68}$ OECD Statistical Extracts (stats.oecd.org) (accessed December 20, 2007).

${ }^{69}$ Fritz Scharpf, "Beschäftigungsorientierte Skrukturpolitik," IIM-LMP Discussion Paper no. 80-92 (Berlin: Wissenschaftzentrum Berlin für Sozialforschung, 1980).

${ }^{70}$ Wolfgang Streeck, "No Longer the Century of Corporatism: Das Ende des 'Bündnisses für Arbeit," Working Paper no. 03/4 (Cologne: Max Planck Institut für Gesellschaftsforschung, 2003); Wolfgang Streeck and Christine Trampusch, "Economic Reform and the Political Economy of the German Welfare State,” German Politics 14, no. 2 (2005), 183-86.
} 


\section{Public Sector Employment and the German Response to FISCAL CRISIS}

Differences in the role of the state and in the size and structure of the public sector help explain this different outcome. First, the relative size of the public sector in Denmark and Germany reflects and reinforces two very different orientations on the part of state actors. In Denmark public sector employment accounts for nearly a quarter ( 23 percent) of total employment, so employment issues figure centrally in the thinking of public officials. In Germany, by contrast, public sector employment amounts to just 11 percent of total employment (of which only 8-12 percent are employed at the federal level, where labor-market policies are set and where wages for the public sector have traditionally been negotiated). ${ }^{71}$ So while German policymakers have also been concerned with the problems of high unemployment, their responses do not reflect first and foremost the concerns of public bureaucrats who expect to be pressed to absorb marginal workers as employees. In fact, through the 1980s German labor-market policy was completely organized around facilitating passive measures (for example, especially early retirement) to remove surplus labor from the market rather than job expansion. Because these measures could be financed through social insurance funds (whose source was contributions by employers and workers rather than tax revenues), this approach allowed the government to avoid tax increases in the short run-although, as we now know, the need to bail out the pension and unemployment insurance funds would eventually become an ongoing source of fiscal drain. ${ }^{72}$

Even without a push by national policymakers for a proactive approach to unemployment, we might have expected public sector bureaucrats at the municipal level to promote such policies, since this is where most public sector workers are employed. (In Germany, 58 percent of public workers are employed by cities. $)^{73}$ Indeed, as we have seen, Danish local bureaucrats formed a powerful constituency within the state for reform because they were the ones who faced having to absorb marginal, lowskill workers into public sector jobs. But municipal actors in Germany

\footnotetext{
${ }^{71}$ Public sector employment figures from OECD, "Highlights of Public Sector Pay and Employment Trends: 2002 Update" (Paris: OECD, 2002), 15; Hellmut Wollmann, "Germany's Trajectory of Public Sector Modernization: Continuities and Discontinuities," Policy and Politics 29, no. 2 (2001); Lorenzo Bordogna, "Industrial Relations in the Public Sector," EIROnline (July 2007); Heiner Dribbusch, "Public Sector Employers' Bargaining Association Collapses," EIROnline (June 2003).

${ }^{72}$ Philip Manow and Eric Seils, "Adjusting Badly: The German Welfare State, Structural Change and the Open Economy," in Fritz W. Scharpf and Vivien A. Schmidt, eds., Welfare and Work in the Open Economy (Oxford: Oxford University Press, 2001).

${ }^{73}$ Dribbusch (fn. 71).
} 
encountered a very different set of constraints and options. On the constraint side, city governments in Germany rely heavily on taxes over which they have no control ${ }^{74}$ and were, in fact, being squeezed by federal and state governments that were themselves facing fiscal crises. ${ }^{75}$ Municipal actors in Germany-staggering under the weight of budget deficits but facing no equivalent pressure to maintain employmentresponded with privatization measures to downsize their own operations and cut their wage bills through reductions in the workforce. ${ }^{76}$ Thus, over the course of the 1990s there was a massive move to allow private actors, especially in transportation, to bid for public jobs. This entailed outsourcing particular bus lines (or schedules), eliminating or privatizing regional rail service, and the like. ${ }^{77}$ The way this downsizing occurred also reflects the distinctive logic of the German context. Since municipalities in Germany are also responsible for social assistance, local authorities sought to avoid having their own redundant workers wind up on the local dole by availing themselves of the very same tools as their private sector counterparts - using early retirement and other mechanisms financed by payroll contributions administered by the social partners but increasingly subsidized directly by the federal government. ${ }^{78}$

In sum, at the same time that municipal actors in Denmark were experimenting with active labor-market policies that they would later press as a model on national policymakers, local bureaucrats in Germany were engaged in rearguard privatization measures designed to cope with suffocating budget deficits visited on them by state and federal actors, who were themselves desperate to bring their own finances in order.

\section{Failed Tripartism and Institutional Fragmentation IN GERMANY}

An integrated national-level reform package based on strong publicprivate coordination might well have expanded the choice sets available

\footnotetext{
${ }^{74}$ With the partial exception of the Gerwerbesteuer, a trade tax levied on business profits, cities rely on tax policies decided at higher levels (state and federal) to raise the money they need to operate.

${ }^{75}$ We thank Wolfgang Streeck for emphasizing the importance of this to us.

${ }^{76}$ See also Wolfgang Streeck, "Endgame? The Fiscal Crisis of the German State," Discussion Paper 07/7 (Cologne: Max Planck Institut für Gesellschaftsforschung, 2007).

77 This is of course in addition to several high-profile national-level privatizations, for example, notably in telecommunications and postal services in 1994 and in preparations at about the same time (mostly workforce reductions) for the later privatization of a significant part of German railway service. See Frankfurter Allgemeine Zeitung, July 11, 1994; International Herald Tribune, April 21, 1993.

${ }^{78}$ Christine Trampusch, "Die Bundesanstalt für Arbeit und das Zusammenwirken von Staat und Verbänden in der Arbeitsmarktpolitik von 1952 bis 2001," MPIfG working paper 02/5 (Cologne: Max Planck Institut für Gesellschaftsforschung, May 2002); see also Christine Trampusch, "Arbeitsmarktpolitik, Gewerkschaften, und Arbeitgeber" (Ph.D. diss., University of Göttingen, 2000), 383.
} 
to local bureaucrats, but in Germany successive efforts at tripartism in the late 1990s and early 2000s all failed. Where the Danish case featured a strong and constructive public-private dualism that helped bring the private sector into the deal, in Germany both the private sector and the public sector are much less united, with the result that alliances are very different and do not typically pit the private sector as a bloc against the public sector. On the labor side, the public sector in Germany is relatively poorly organized by international standards ${ }^{79}$ and a significant number of public sector workers are highly skilled career civil servants (Beamte) who enjoy lifetime employment guarantees and whose interests are quite different not just from private sector employees but also from public sector workers working under normal employment contracts. ${ }^{80}$ In addition, the union to which many public sector workers belong (ver.di) also organizes private sector services, and its alliance strategies reflect political tendencies more than differences of interest between sheltered and exposed sectors. ${ }^{81}$

Moreover and as already alluded to, there is serious fragmentation and disunity among public sector employers as well. The political dynamics - and tensions - across different levels of government described above contributed to ongoing conflict and sustained an unproductive "shell game" in which public authorities at the federal, state, and local levels of government jockeyed to shift the burdens of adjustment among themselves. ${ }^{82}$ These tensions also ran through wage negotiations and came to a head in 2003 when, after forty years of unified public sector bargaining, the collective bargaining association for the public sector collapsed, first as municipalities defected on pension issues and then states broke off from the system of bargaining traditionally led by the federal government. ${ }^{83}$

\footnotetext{
${ }^{79}$ According to Visser, union density in the German public sector is 56 percent, which puts Germany in eleventh place among the seventeen countries for which he has data (mid- to late 1990s). While this level of unionization is above the average for all employees in Germany, it is below the organization rates for public sector workers in many other nations, particularly the Nordic countries. See Jelle Visser, "Trends in Unionisation and Collective Bargaining" (Geneva: ILO, September 2000).

${ }^{80}$ Bordogna (fn. 71). A large number of these Beamten are employed at higher levels (federal and state), contributing to a disconnect with municipal leaders, who are more likely to be dealing with lower-skill, lower-status workers.

${ }^{81}$ Martin Höpner, "Der organisierte Kapitalismus in Deutschland und sein Niedergang," in Roland Czada and Reinhard Zintl, eds., Politik und Markt 34 (2003).

${ }^{82}$ Trampusch (fn. 78), passim.

${ }^{83}$ Dribbusch (fn. 71). There has been a partial reconsolidation as local governments try to avoid competition among themselves and seek shelter behind the federal government, but states still bargain separately, and in the meantime privatization has resulted in growing number of workers outside the public deals. See Heiner Dribbusch, "New General Framework Agreement Signed in Public Services." EIROnline (2005).
} 
In light of the divisions and conflicts even within the state itself, it should come as no surprise that all efforts at tripartism foundered on the inability of state actors to enlist the support of the private sector in a sweeping reform effort. In the realm of collective bargaining, the German government does not have the same tools available as the Danish state does to intervene and force settlements. The principle of collective bargaining autonomy (Tarifautonomie) is firmly enshrined in the German constitution and mandates strict noninterference by the state. Thus, the kind of government intervention in wage negotiations described above, which was so crucial in Denmark in 1998 as a turning point, is ruled out institutionally in Germany.

In terms of political dynamics, the social partners in Germany were also not interested in any reforms that would have called into question Germany's long-standing system of self-administration in the welfare and social insurance funds. ${ }^{84}$ Moreover, powerful public and private sector actors fought hand-to-hand with municipal bureaucrats to oppose the federal government in all efforts to cut subsidies to the social insurance funds, on which they had all-in their different ways-come to rely (firms and their local workforces to underwrite peaceful downsizing, municipal governments to balance their budgets). Analysts close to the ill-fated Alliance for Jobs initiative (Bündnis für Arbeit) emphasize that tripartism in Germany failed in large part because the state lacked the tools and leverage that would have been necessary to force or elicit the compliance of the private sector in a broad reform effort. ${ }^{85}$

The Hartz reforms emerged more or less directly out of the impasse that was reached in tripartite bargaining between business, labor and the state, and reflected a turn away from negotiated solutions to unilateral state action. In fact, significantly in the present context, what precipitated this reversal was a scandal over manipulating placement statistics that engulfed the Federal Employment Office (administered jointly by the social partners). ${ }^{86}$ The sitting Social Democratic chancellor, Gerhard Schröder, seized the moment to appoint a decidedly nontripartite commission for labor-market reform headed by the former personnel director of Volkswagen and including twenty-one members, of which only two were trade union representatives and just one a representative of organized business. ${ }^{87}$ Space does not permit a full evaluation of the

\footnotetext{
${ }^{84}$ Streeck (fn. 70).

${ }^{85}$ Streeck (fn. 13); Streeck (fn. 70).

${ }^{86}$ Trampusch (fn. 78).

${ }^{87}$ Not even from organized industry, but rather from the handicraft sector. See Streeck and Trampusch (fn. 70), 184.
} 
labor-market results of the package of reforms undertaken under the auspices of the Hartz commission. For present purposes, however, and with respect to the political outcomes with which this article is centrally concerned, it is clear that the Hartz reforms both reflect and reinforce the erosion of macrocoordination and mark a turn away from a tradition of at least informal government consultation with the social partners on labormarket issues. ${ }^{88}$ Moreover, social partnership at the local level has also been eroded in that the reorganization of the Federal Labor Office (in response to the scandals) involved among other things the privatization of many placement services, further limiting the role of social partners and for that matter public bureaucrats at the local level as well.

Overall, then, it seems clear that unlike in Denmark, the public sector in Germany has not been a force encouraging unity and cooperation among private sector actors, and indeed developments over the course of the 1990s and 2000s suggest, if anything, that public sector actors in Germany cannot themselves organize and coordinate their own activities effectively.

In sum, on all three dimensions cited above, the Danish and German cases contrast sharply.

1. State as employer. In Denmark public sector actors pushed for policies that would allow them to share the burdens of dealing with unemployed and marginal workers with private sector firms, while in Germany local authorities engaged in rearguard cost-cutting measures, the centerpiece of which-privatization - reduces the presence of an already small public sector. Hartz IV has done nothing to inspire greater public-private coordination; nor has it mitigated tensions across different levels of government. Instead, local bureaucrats in Germany are busy trying to shift the burden of marginal workers back to the national government by getting social assistance clients reclassified as "able to work" so that they fall under the new, harsher, Hartz IV support, funded by Berlin.

2. State leverage in collective bargaining and tripartite channels. A large public sector in Denmark supported tripartism by prompting unity and collective action by private sector actors. In Germany, by contrast, failed tripartism and a weak, fragmented public sector presence in collective bargaining have done nothing to counteract the fragmentation of interest associations in the private sector or to spur them to greater cooperation and coordination.

3. Impact on private sector actors. Fragmentation and lack of unity among state actors in Germany has meant, in turn, that private sector actors have no real incentives to assume responsibility for marginal groups. Continuing high unemployment entails minimal competition for workers, and even the current workforce is at risk for unemployment. Whereas recent

${ }^{88}$ Streeck (fn. 70). 
developments in Denmark have expanded the role and responsibilities of the social partners beyond their traditional jurisdiction in labor-market regulation into social policy broadly construed, in Germany, the trend has gone decisively in the opposite direction-with politicians taking unilateral control in areas (labor market and social policy) traditionally negotiated with the social partners, even as unions and employers continue to hunker down and defend their rights to bargain collectively without state interference, albeit for a shrinking constituency. ${ }^{89}$

\section{CONCLUSION}

This article has investigated the puzzle of recent institutional change within coordinated market economies. In particular we have examined why Denmark has been able to maintain high levels of macrocoordination and social solidarity, while Germany has experienced significant institutional erosion. Although Denmark had more centralized wage bargaining even in the 1970 s, the two countries looked fairly similar, with a high degree of organization among employers and strong national-level coordination led by manufacturing. Yet by the 1990s a sharp disparity was evident. Even though Denmark had decentralized collective bargaining to the industrial level, it created national framework agreements to coordinate bargaining and preserved strong political macrocoordination in policy-making channels, emerging as a European success story in mobilizing private actors to incorporate the unemployed. In comparison, Germany experienced significant institutional erosion, with a narrowing of collective bargaining coverage and a shrinking role for the social partners in social policy and labor-market governance. In the wake of dramatic failures of efforts to negotiate reforms in the context of tripartite bargaining, the government unilaterally instituted reforms that largely exacerbate rather than ameliorate the divide between labor-market insiders and outsiders.

We attribute this divergence between Denmark and Germany to differences in the role of the state and the size of the public sector, which in turn have been associated with differences in the mode of coordination that has traditionally prevailed in the two countries. We suggest that the emphasis in the varieties-of-capitalism framework on employer coordination often ignores the state's role in organizing and sustaining this coordination. In addition, the dichotomous categories around which the framework is organized renders it somewhat ill equipped to capture important status quo ante differences in the type

\footnotetext{
${ }^{89}$ Streeck (fn. 70); Christine Trampusch, "Sozialpolitik in Post-Hartz Germany," Welttrends 13, no. 47 (2005).
} 
of coordination at work, as well as the resulting divergent trajectories we observe today. Because coordination is not self-sustaining and needs to be actively sustained and nurtured, the essential categorization of regimes should focus on processes rather than functional structures. We therefore propose subcategories grounded in processes and suggest that the varied capacities for renegotiation within these subcategories reflect, above all, differences in the role of the state. In short, the broader implication of our analysis for debates on varieties of capitalism is to suggest the need for an alternative framework for classifying and analyzing different varieties of CMEs that attends to the level at which coordination is achieved and to the role of the state and public sector in the politics of coordination.

The question of how states coordinate becomes especially salient in light of recent research, which suggests that countries with higher levels of macrocorporatism do better than those relying more exclusively on enterprise cooperation at preserving social solidarity or at narrowing the zero-sum conflicts between various groups in society and including labor-market outsiders. Although the focus of this article is to explore how structures for achieving coordination at the national level are sustained, our interest in these outcomes flows from a large body of research that finds that state-led coordinating mechanisms are better able to sustain a commitment to collective goods than are nonstate avenues for coordination. For example, Martin and Swank find that macrocorporatism leads to higher levels of spending on active labormarket policy in eighteen developed democracies, whereas enterprise cooperation does not produce this effect. ${ }^{90}$ According to Kenworthy, a high employment strategy-consistent with high levels of macrocorporatism-can produce an optimal measure of growth, employment, and equality. ${ }^{91}$ Huber and Stephens suggest that the problems of countries lacking strong mechanisms for macrocorporatism in part reflect low overall employment levels and limited opportunities for women in the labor force. ${ }^{92}$ For Carlin and Soskice, countries with low employment and low levels of macrocorporatism have experienced a crisis of underconsumption. ${ }^{93}$ Thus, distinctions in coordinating capacities may very well hold the key to differences in the capacities of countries to maintain social solidarity in the contemporary period.

The evidence we have presented here is necessarily suggestive rather

\footnotetext{
${ }^{90}$ Martin and Swank (fn. 15).

${ }^{91}$ Kenworthy (fn. 41).

${ }^{92}$ Huber and Stephens (fn. 37).

${ }^{93}$ Carlin and Soskice (fn. 36).
} 
than definitive, and further work will have to be done on a broader range of countries to yield a full test of the propositions we have laid out above. This constitutes an important research agenda, not least because our argument points to the need for a profound revision of the conventional wisdom on the role of the state and the public sector in the politics of coordination. Recent important work investigating how nations with high levels of social solidarity can achieve a felicitous mix of growth and equity ${ }^{94}$ tends to neglect the political coalitions on which this high road to economic growth is based and especially the way in which these coalitions are forged and sustained. We seek to fill this gap with our argument about the potential political impact of the public sector, specifically, how state actors and a large and well-organized public sector can shape the interests and strategic options of other key actors in the political economy. Our findings call into question the neoliberal mantra that the state is always a problem and the public sector is always a drag on adjustment. But it also unsettles another less ideologically charged truism in comparative political economy - that export-sector leadership will produce the best collective outcomes. The Danish and German experiences imply that although public sector employment has been considered part of the trilemma of the postindustrial economy, it may also be part of the solution: in Denmark a large public sector provided state strategic actors with both incentives to continue strong macrocorporatist bargaining and greater influence over private sector actors in political processes of negotiation.

In short, a large public sector can be a crucial political support for continued macrocoordination in the postindustrial economy. Our analysis thus attempts to promote a deeper understanding of the way that the state matters and to move beyond government as instrumental actor to government as setting the terms of engagement, or the "war of position" in the words of Antonio Gramsci. Recent analyses of the state's role focus excessively on the instrumental influences of politicians on policy outcomes, to the neglect of the broader contextual impact of a large public sector on processes of institutional change. Our analysis, by contrast, draws attention to the role of the state as the elephant in the room in setting the terms of the war of position in the struggle to sustain social solidarity in the twenty-first century.

${ }^{94}$ For example, Kenworthy (fn. 41). 